\title{
Un-earthing the Eighteenth-Century Churchyard: Charlotte Smith's Life Writing Among the Dead
}

\author{
James Metcalf
}

King's College London

\begin{abstract}
The work of poet and novelist Charlotte Smith (1749-1806) has been consistently associated with life writing through the successive revelations of her autobiographical paratexts. While the life of the author is therefore familiar, Smith's contribution to the relationship between life writing and death has been less examined. Several of her novels and poems demonstrate an awareness of and departure from the tropes of mid-eighteenth-century 'graveyard poetry'. Central among these is the churchyard, and through this landscape Smith revises the literary community of the 'graveyard school' but also its conventional life writing of the dead. Reversing the recuperation of the dead through religious, familial, or other compensations common to elegies, epitaphs, funeral sermons, and 'graveyard poetry', Smith unearths merely decaying corpses; in doing so she re-writes the life of the dead and re-imagines the life of living communities that have been divested of the humic foundations the idealised, familiar, localised dead provide. Situated in the context of churchyard literature and the churchyard's long history of transmortal relationships, this article argues that Smith's sonnet 'Written in the Church-Yard at Middleton in Sussex' (1789) intervenes in the reclamation of the dead through life writing to interrogate what happens when these consolatory processes are eroded.
\end{abstract}

Keywords: Charlotte Smith, graveyard poetry, churchyard, death 


\section{INTRODUCTION}

Poet and novelist Charlotte Smith (1749-1806) is rarely included in critical accounts of the 'graveyard school' of poetry. This group of four mid-eighteenth-century male poets-Thomas Parnell, Robert Blair, Edward Young, and Thomas Gray-is typically categorised by its melancholy meditations 'upon the transience of life, the imminence of death, and (on most occasions) the consolation accorded by a Christian afterlife'. ${ }^{1}$ In this article I document Smith's relationship to 'graveyard poetry' through a fundamental but generally overlooked topos: the churchyard. Though the churchyard is often seen as a conventionally appropriate setting for gloomy contemplation, I argue that for Smith it is a space of life writing among the dead. In 'Sonnet XLIV. Written in the Church-Yard at Middleton in Sussex' (1789) Smith disrupts the literary community of the 'graveyard school', as previous critics have observed. In doing so, however, she also overturns this earlier literature's recuperation of the deceased through religious, familial, or other subjective processes of recovery, uprooting the collective dead as the basis of living community. After an introduction to Smith, her work, and her life writing practice, I explore the concept of the churchyard as a site that underpins identity and community for the living, before a close reading of 'Sonnet XLIV' that situates Smith in this context. While this article focuses on a single poem, I therefore place it in a long tradition of churchyard literature that has consistently and variously written the life of the dead and their relationship to the living.

Charlotte Smith's best-known collection of poetry-the Elegiac Sonnets first published in 1784-was written from King's Bench Debtor's Prison, where she served part of a sentence with her husband. When she separated from him in 1787 she increased her literary output, at least partly to support their children who were denied their paternal grandfather's inheritance. By the end of her life Smith had produced eight further expanded editions plus many other works, including long poems, translations, a play, children's books, and ten novels. Many of these texts incorporated the autobiographical revelations that have come to characterise Smith's writing to the extent that Stuart Curran sees her 'intrusion of "real life" into the world of romance' as 'the beginning of a reconstituted literary realism'. ${ }^{2}$ Smith's most forthright revelations appear in successive prefaces: in the first and second editions of the Elegiac Sonnets she hints at the 'very melancholy moments' behind her poetry, later reversing her suggestiveness through a series of disclosures that draw clear connections between her life and her writing. ${ }^{3}$

Smith's sustained self-reference prompted both eighteenth-century reviewers and modern critics to read her work as an exemplary form of 
life writing, in which encompassing paratexts provide an 'on-going plot' that informs the reading of her texts. ${ }^{4}$ According to The European Magazine for 1793, Smith's poem The Emigrants (1793) was the product of a writer 'whom we can discover almost at the bottom of every page, as we may the portrait of some of the most renowned painters in the corner of their most favourite pictures'. ${ }^{5}$ And an anonymous 'Sonnet to Mrs. Smith' in the 1786 European Magazine valued her poems precisely because they 'spring from REAL woe'. ${ }^{6}$ It is now common critical practice to read the Elegiac Sonnets through their autobiographical paratexts $;^{7}$ successive personae are interpreted as the author made present in the fictive scene; ${ }^{8}$ and Smith's innovations in the sonnet form have also been read as autobiographically inflected. ${ }^{9}$ As so many of Smith's poems are located in Sussex, where she lived for much of her life, critics have also situated this life writing in specific autobiographical locations, guided by sonnet titles including 'Written in Farm Wood, South Downs, in May 1784' and 'Written at Penshurst, in Autumn 1788'. ${ }^{10}$

Much of this work usefully connects Smith's internal and external landscapes. Theorists of life writing and space have argued that the textual communication of identity relies on location, that external physical space is related to internal mental space, and that life writing is able to focus on the connection between the autobiographical centre of consciousness and surrounding reality. ${ }^{11}$ Literary techniques such as deixis and indexical pronouns (I/here, you/there) place the subject and demonstrate the ways in which '[s] patial schemata are tied to the human body and to bodily orientations' and how 'utterances are tied to a specific location of enunciation'. ${ }^{12}$ The relationship between the writing self and the space of literary composition can be productively read as what Helga Schwalm calls 'topographical life writing'-a sub-genre that 'locates life courses and self-representations in specific places', bringing into play 'topography as a pivotal moment of biographical identity'. Realised through a structure of peripatetics, topographical life writing 'designates a specific nexus of life writing, space, poetic reflection and walking' which Schwalm sees 'at the heart of poetic self-reflexivity towards the end of the long eighteenth century'. ${ }^{3}$

Though William Wordsworth is Schwalm's primary example, Smith demonstrates an earlier intersection of life writing and experience of landscape. Localising the poems in real and personal places validates their emotional subject matter; locodescriptive titles attach poems to specific times and places, and this correlation is often supported by their content, which relates the expression of feeling to a compositional environment. ${ }^{14}$ As David Fairer highlights, Smith's poetry characteristically shifts from sense impressions of an external landscape to inner reflections and back 
again, using the sonnet's capacity to affirm poetic identity by featuring 'a textual self, repeatedly reflecting on, and being reflected by, the natural world'. ${ }^{15}$ Critics have therefore highlighted the 'tactile poetics' of Smith's 'earth-bound aesthetic', focusing on the relationship of the narrator to a living, haptic earth. ${ }^{16}$ Smith's practice of life writing among the dead, however, has been less examined. When the landscape is the churchyard and the living persona's contact with the earth is juxtaposed with that same earth's disclosure of the buried corpse, I argue, this relationship is brought into tension that highlights ruptures of community-living, literary, and dead.

\section{LIFE IN THE CHURCHYARD}

The churchyard is prominent among Smith's characteristic landscapes, featuring in seven novels and six poems. As she shrewdly engaged with literary trends, this recurrence has been read as a strategic positioning that draws on the popularity of churchyard settings after Thomas Gray's Elegy Written in a Country Churchyard (1751). ${ }^{17}$ While Smith demonstrates her familiarity with the tropes of the 'graveyard school', she also intervenes in their male literary coterie, in the process re-defining the masculine community of the living and the dead codified by Gray's 'rude forefathers of the hamlet'. ${ }^{18}$ In 'Sonnet XLIV' Smith removes the churchyard from the centre of a rural settlement to a margin of the Sussex coast; where the dead were formerly disclosed as sleeping moral stewards of their community, maintaining their membership of the living society they underpinned before being respectfully covered over once more, Smith exhumes their status as insensible corpses dramatically detached from the living.

It is significant that Smith's process of exposure and revelation takes place at the coast-an environment defined by John R. Gillis as the originary human landscape. Occupied for millennia and therefore shaping the species, the history of the inhabited coastline is one 'of cocreation'. However, it is also 'at the edge of the sea that we imagine both the birth of new worlds and the death of old ones'. ${ }^{19}$ Roger Caillois similarly interprets the coast as a liminal site of simultaneous life and death, describing the beach as a natural cemetery where animals gather 'to expire in a first and fatal intimacy'. In the coastal context of Caillois' Patagonia, human bodies are absent from the 'belated rendezvous' of nature's shoreline waste and are instead enclosed in the burial ground, constructed to resist the 'law of universal and terrible destruction'. Man 'gathers his companions' remains and tries to keep the shape of their bodies intact. He safeguards 
his own likeness against carnivores, surf, and wind. In vain, he protects an integrity that everything attacks and shatters'. The graveyard is 'a tidy haven for their disgusting flow', but it is also the first mark of civilisation: 'the grove devoted to the dead, which founds in the solitude of nature the start of a human landscape'. ${ }^{20}$

By the eighteenth century the churchyard was well established as a human landscape. As a space marked by occupation and livelihood it instantiates what Thomas W. Laqueur calls a 'deep time' of memory and communal idealisation rooted in the English environment and culture: the churchyard's 'necrogeography' was a 'naturalised feature of the landscape', so pervasive as to be 'intimately present in the daily life and the minds of the living, ${ }^{21}$ Phillipe Ariès refers to the churchyard in this period as 'the public place par excellence, the centre of collective life'..$^{22}$ It was 'a focal point of community' throughout the Middle Ages and in many instances up to the eighteenth century: it hosted sanctuary and dwelling, business and manufacture, pasturage and storage, public meeting and politics, justice and education, entertainment and performance, and religious rites of baptism and marriage as well as burial. ${ }^{23}$ Every feature of the churchyard landscape was put to use for the benefit of the living and the parish was collectively responsible for its upkeep. ${ }^{24}$ From the churchyard's ancient origins and into the eighteenth century, living and dead 'coexisted in the same places and behind the same walls', the church forming the centre of Christian community and the churchyard facilitating that centrality; this site was a territorial extension of the church's custodianship of life as well as afterlife, a physical manifestation of the parish with its ties of communal experience and geographical rootedness. ${ }^{25}$

As Mikhail Bakhtin proposed in his theory of the chronotope, the rural communities commemorated in Gray's Elegy preserved an ancestral bond with the land in their 'concrete, spatial corner of the world where the fathers and grandfathers lived and where one's children and their children will live'. This localised 'sequence of generations' was sustained 'by the age-old rooting of the life of generations to a single place, from which this life, in all its events, is inseparable'. In a shared space deeply rooted in time, 'temporal boundaries between individual lives and between various phases of one and the same life' are weakened. ${ }^{26}$ Such ties were most obviously expressed in the churchyard, where the 'forefathers of the hamlet sleep' (Gray, Elegy, 1. 16). Here the dead are markers of a collective chronotopic relationship-remainders of the past and reminders of the passage of time for the living. The 'same life' shared by generations includes the dead, and their occupation of the churchyard centres this collective temporal porosity in a defined space, the features 
of which confirm a continuity of inhabitation and familiarity. In the English country churchyard human narrative 'take[s] on flesh'. ${ }^{27}$

The dead of the churchyard were therefore a part of the living community that surrounded them-indeed, they were its foundation. As Laqueur states, the dead are 'social beings', they 'make social worlds'; 'they structure public spaces' like the churchyard by 'announc[ing] their presence and meaning by occupying space'. Dead bodies 'create a community of memory; visitors to these bodies confirm it; together they make a claim on space and on the attention of the living'. ${ }^{28}$ For Caillois this continuity of presence and memory extends into succeeding generations, and ' $[\mathrm{t}]$ his is how a civilisation appears'. ${ }^{29}$

This twentieth-century conceptualisation of the churchyard has roots in the eighteenth century's Enlightenment history of death. ${ }^{30}$ For Alan Bewell, Robert Lowth's Lectures on the Sacred Poetry of the Hebrews (1753) and Giambattista Vico's New Science (1725) are exemplary sources in this project. Lowth's argument, summarised by Bewell, contends that 'the key to all our metaphors for death [...] is to be found in what we see happening to or what we do with the bodies of the dead [...] The history of death, then, is the history of our organisation, displacement, and metaphoric embellishment of this encounter'. ${ }^{31}$ Vico similarly asserted the connection between the place of the dead and ideas about the afterlife; in tracing the etymology of the noun humanitas - human civilisation-to the verb humare - to bury-he positions burial as one of the three founding principles of human institutions (alongside religion and marriage). Our ancient forefathers, Vico writes, 'came to found and divide the first dominions of the earth' through 'protracted settlement and the burial of their ancestors [...] The lords of these domains were called giants, a Greek word which means "sons of the earth", or descendants of the buried dead'. While he charts agricultural organisation of the landscape to this first claiming of space and meaning, Vico also argues that burial marks the beginning of religious space, or hallowed ground, which is synonymous with the burial site. ${ }^{32}$ Robert Pogue Harrison, who extends Vichian thought to 'whatever else relies on the transmission of legacy', agrees that, as 'humans dwell, the dead, as it were, indwell-and very often in the same space', and that this combination of institutional inheritance and spatial proximity has its foundations in burial: 'humans bury [...] to humanise the ground on which they build their worlds and found their histories.'.33

For Adam Smith in The Theory of Moral Sentiments (1759) the presence of the dead in living communities was also essential to the moral circulation of society. According to Esther Schor's reading, as we imaginatively take our place in the grave "the dead take up their places within our 
minds', and this exchange is the basis for 'a dynamic, circulating, sympathetic culture of mourning'. ${ }^{34}$ Smith interpreted our feelings towards the buried dead as the first iteration of sympathy, as our memorial 'tribute' seeks 'artificially to keep alive' those who are lost but imaginatively whole and sensible in the ground. ${ }^{35}$ As Schor points out, poets inherited 'Smith's notion that culture is founded at the grave'. ${ }^{36}$

Churchyard literature engages with the continuity and community of the churchyard, ensuring that it remained 'at once topography and a topos' - a landscape given literary form and thereby kept culturally exigent. ${ }^{37}$ The churchyard in Gray's Elegy is 'a visible, socially and juridically defined, narrowly bounded, hierarchic parish community of the dead through time [...] they were seen to be there in the contours of the ground and felt to be there through the verse'. ${ }^{38}$ There is a reassuring relationship between the ploughman working the soil, the poet walking the lawn, and the dead beneath the feet of both, even if these layered relations remain problematic. In earlier, more emphatically religious churchyard literature the dead do not appear as the supportive basis for poetry and community, but instead frequently emerge as grotesque cadavers that disturb and disgust. Nevertheless, exhumation is resolved as the dead are ultimately covered over with the literal turf of the churchyard and the metaphorical processes of Christian immortality. Robert Blair's The Grave (1743), for instance, indulges in visceral description of the exposed corpse, yet 'this ado in Earthing up a Carcase/That's fall'n into Disgrace, and in the Nostril/Smells horrible' is reversed with a vision of the reconstituted, perfected body at the Resurrection: by the end of the poem 'the loose scatter'd Parts' are re-assembled and 'ev'ry Joint posses[es] its proper Place,/With a new Elegance of Form' ${ }^{39}$ With a sentimental instead of an evangelical emphasis, Gray's Elegy similarly observes the buried dead but protects their memory from decomposition by re-imagining their lives in idealised pastoral terms. As the narrator prophesies his own death he hopes for a 'kindred Spirit' to likewise preserve his memory and his dignity by remembering without inquiring too closely: 'No farther seek his merits to disclose,/Or draw his frailties from their dread abode' (11. 125-26).

In its practice of imaginative exhumation and religious or sentimental re-covery-an interconnected process of physical concealment and emotional reclamation-mid-eighteenth-century churchyard literature inherits established methods of life writing for the dead: the deceased, accessible in the churchyard and available to the reconstitutive imagination, continue to uphold the community of the living. Though rarely using these terms, critics have highlighted the continuities between funeral sermons, epitaphs, elegies, and 'graveyard poetry'. ${ }^{40}$ These Christian 
genres focused on death as the event initiating a contemplative process of memento mori, which ends with a renewed understanding of the supremacy of the afterlife. They are invested 'in reparation, resuscitation, and reclamation', as Diana Fuss writes of elegies; they attempt 'to buoy the living by holding on to the dead', either as perfected celestial souls or familiar forefathers. ${ }^{41}$

Repeating this legacy, however grimly fixated on decay it may appear, much churchyard literature before Charlotte Smith writes the life of the dead in essentially orthodox terms: its eschatology paradoxically constitutes a point of origin, not to be feared but rather prepared for with hope. Smith participates in this practice, though less an heir to tradition than a frustrated observer of the absences of sympathy between the living and the dead. In 'Sonnet XLIV' the juxtaposition of abject and animate bodies resolved in earlier churchyard literature remains exposed, revealing the churchyard as a site of tension in which the formerly consoling earth is dramatically un-earthed-dispossessed of its dead and deprived of its physical and symbolic stability for the living.

\section{LIFE WRITING AMONG THE DEAD: 'SONNET XLIV'}

The churchyard recurs frequently in Smith's work. The novel Montalbert (1795), for instance, contains an extended reflection on the churchyard, in which Mrs. Vyvian describes the congeniality of this scene to 'the gloomy temper of my soul [...] none seemed to suit me so well...... I found a melancholy sort of satisfaction in indulging the sad thoughts that incessantly pressed on my mind'. ${ }^{42}$ Throughout Smith's fiction the churchyard is a site of reflection which is also consistently associated with poetry: Ethelinde quotes Romeo and Juliet, Desmond cites Gray's Elegy, and in Celestina (1791) the protagonist remembers Thomas Edwards' sonnets while reading the tombstones. In Celestina, Montalbert, and Marchmont (1796) these literary associations also prompt characters to produce their own poetry of (and in) the churchyard.

Some critics have read Smith's use of the churchyard as a claim to its literary authority, associated with a long-standing tradition of popular poetry ${ }^{43}$ others have highlighted how Smith 'dramatically revises the topos of the tranquil country churchyard'. ${ }^{44}$ Schor, for example, interprets the active verbs of 'Sonnet XLIV' as an assertion of Smith's 'gendered exclusion' from the patriarchal peace of Gray's 'rude forefathers'; ${ }^{5}$ and Ingrid Horrocks argues that the wandering activity of Smith's speakers in the churchyard is a 'specifically female, and specifically politicised, mode', as 'charming and accepting melancholy' becomes 'intense, mobile, and furious social alienation' ${ }^{46}$ Jacqueline M. Labbe argues that 
the 'standard genealogy' connecting the 'Graveyard School' to Romanticism and the Gothic becomes 'increasingly untenable' once women writers are included in literary histories. ${ }^{47}$ As Bethan Roberts summarises, the "transforming forces at work within the scene of sonnet XLIV become emblematic of the revisioning force Smith brings to the form, and of her departure from her predecessors'. This is 'played out upon the churchyard landscape', implicating this space in the negotiation of literary tradition and reputation. ${ }^{48}$

Smith calls on this community's figurehead, Thomas Gray, through his 'Sonnet on the Death of Mr Richard West', amending the original line-'In vain to me the smiling mornings shine'- to 'But vain to them the winds and waters rave'. ${ }^{49}$ Smith uses Gray's influence but crucially transfers her allegiance away from the 'rude forefathers' of his Elegy by unearthing their reality as deracinated bones on the shore. Smith therefore offers an 'ironic critique of Gray's idealised community centred on the grave', Schor concludes, but she 'also authorises her poem by invoking a feminine goddess [the moon] hostile to the sanctity of Gray's "unhonoured" dead'. ${ }^{50}$ The 'loud equinox' that generates the poem's environmental energy suggests the coincidence of the full moon with high spring tides - those 'with the biggest difference between high and low water'-at a peculiarly active time of year. ${ }^{51}$ This confluence of the animating lunar tides is particularly significant for a woman writer contributing to and commenting on a traditionally male poetics and the gendered conception of dead 'forefathers' ${ }^{52}$

Schor also notes that the bones in Smith's coastal churchyard suffer the same watery fate as John Milton's Lycidas-another (masculine) elegiac ancestor of the 'graveyard school' ${ }^{53}$ As Rebecca Mills has shown, the elegiac tradition from Lycidas (1638) onwards frequently locates the dead by or in the sea, drawing on its association with 'destruction and death, and the shore as a liminal and often uncanny zone' where the anxieties of mortality are expressed in 'the slippery and shifting ground'. ${ }^{54}$ This is true of 'Sonnet XLIV'; nevertheless, while Smith claims this tradition she also disrupts its continuity. Milton organised 'the chaotic sea [to] become a site of responsive winds, order, and hierarchy', transferring the powers of the destructive environment to an elegiac landscape that mourns the deceased; in this transformed 'Arcadian imagined geography' Lycidas is recovered, allowing the poem to end with hope of resurrection. ${ }^{55}$ By contrast, Smith's dead are washed away by an indifferent sea.

In this section of the article I read 'Sonnet XLIV' as Smith's intervention in this literary context, placing the poem within the varied and long-standing tradition of the life writing of the dead. As an example of Smith's contributions to churchyard literature this text is part of, and 
responds to, an extensive and enduring culture of the churchyard in the long eighteenth century. According to this reading, 'Sonnet XLIV' disturbs more than literary categories. The churchyard dead of earlier poetry support the poet's wandering feet and discursive poiesis, thus representing the subterranean stability and continuity of the surrounding rural and religious community. In Smith's poem, bones are startlingly torn from their graves to reveal the uncanny animation of the dead in the landscape and the dramatic absence of their foundational place in the narrator's sense of self and society.

Press'd by the Moon, mute arbitress of tides, While the loud equinox its power combines, The sea no more its swelling surge confines, But o'er the shrinking land sublimely rides. The wild blast, rising from the Western cave, Drives the huge billows from their heaving bed; Tears from their grassy tombs the village dead,* And breaks the silent sabbath of the grave!

With shells and sea-weed mingled, on the shore Lo! their bones whiten in the frequent wave;

But vain to them the winds and waters rave; They hear the warring elements no more:

While I am doom'd-by life's long storm opprest, To gaze with envy on their gloomy rest.

*Middleton is a village on the margin of the sea, in Sussex, containing only two or three houses. There were formerly several acres of ground between its small church and the sea, which now, by its continual encroachments, approaches within a few feet of this half-ruined and humble edifice. The wall, which once surrounded the church-yard, is entirely swept away, many of the graves broken up, and the remains of bodies interred washed into the sea; whence human bones are found among the sand and shingles on the shore.

The sonnet begins with a passive verb-the object of the Moon's pressure, not revealed until the third line, is the sea-which nonetheless suggests activity in the landscape. 'Press'd' into action by the 'mute arbitress', the sea is also personified and quickly reverses implied passivity by breaking the confinement of its 'swelling surge' and imposing upon 'the shrinking land', over which it 'sublimely rides'. Coupling the Moon's rousing force with the 'swelling surge', the poem presents air and water as the animating elements: wind and sea, which 'drive', 'tear', and 'break', are external energies capable of impressing the land, the dead, and the abstract 'silent sabbath of the grave'. Their relationship with the dead 
is not, however, purely violent. There are suggestive parallels, as the sea breaks both its own and the dead's state of confinement, and the 'heaving bed' of the 'huge billows' implies a metaphor of restless sleep often applied to the dead-as for Gray's 'rude forefathers', who 'sleep' 'where heaves the turf in many a mouldering heap' (1. 14). Like the sea driven from its bed, the dead are un-coffined and unconfined.

This unsettling event at the centre of the poem (literally, as lines seven and eight, but also symbolically) reveals the extent of the storm's destruction. The dead are 'the village dead', belonging to a place from which they have been violently torn (displaced and dis-placed); the religious protection afforded by burial is also rendered ineffectual, as 'the silent sabbath of the grave' is broken. Unlike the ruins of much churchyard literature, the church at Middleton was in use until 1838 and was therefore the spiritual centre of the community. ${ }^{56}$ In these lines the dead are thus locally and spiritually divested, disconnected from the living whose recuperative processes are revealed as empty consolations.

This is all the more shocking as Smith's note confirms the reality of her description, placing an apparently fictive event within the author's biographical landscape.$^{57}$ It therefore complements the title, which reproduces the trope of poetic activity in the churchyard ('Written in...'). Through both paratexts Smith verifies the directness of her narrator's experience and authenticates the inner claims of the poem. In this churchyard context the footnote is also a buried object brought to the surface, as the poem's dead are disinterred by the sea. ${ }^{58}$ The note therefore emerges as a vital thing, placing the text within a live reality mediated by the writer, who creates her poem in a highly particularised landscape. In Gérard Genette's terms the footnote contributes 'textual depth', earthing the discourse ${ }^{59}$ it therefore also provides a chthonic grounding to a sonnet whose earth is characterised by instability-Middleton is marginal, suffering erosion every year. Earthly attrition has claimed more than soil and stone, however, as the village itself-embodied in the remains of its ancestors and spiritually represented by the now 'half-ruined and humble' church-is 'swept away. ${ }^{60}$

A decade before the sonnet was published St Nicholas' Church was already renowned for its coastal precarity. ${ }^{61}$ Between Smith's poem and its complete collapse, picturesque tourists associated the site with her sonnet. A letter published in The Gentleman's Magazine in 1796 claimed that the 'ruinated church, and sea-washed cemetery, have been retrieved from obscure oblivion by the poetical painting of Charlotte Smith' ${ }^{62}$ The following year another commentator described the scene and quoted the sonnet, claiming that 'insignificant as the church appears [...] it has been immortalised by the elegant pen of that poetess of the county'. ${ }^{63}$ 
As Roberts observes, these responses misread the poem, which 'becomes bound up with retrieving and somehow preserving the site [...] even as it describes and heralds its destruction'. ${ }^{64}$ In J. B. Davis' The Origin and Description of Bognor or Hothampton (1807) the tone becomes more elegiac: quoting the sonnet as an example of the church's 'celebrity from having furnished the scene of one of the poetical compositions of the late ingenious and unfortunate Mrs. Charlotte Smith', Davis also acknowledges the loss of both 'relic'- 'which will soon lose every vestige of existence'and poet (Smith died the previous year) ${ }^{65}$ In subsequent accounts Smith, like the churchyard, has vanished from the landscape. ${ }^{66}$

As the poem progresses, the sea's supremacy over the earth is confirmed and bones mingle with oceanic detritus. Deprived of their humic and human status, the remains return to a natural or animal state, joining Caillois' littoral aggregation. As the speaker enters the poem in the final four lines, she draws a distinction between the insensible 'They' and the all too sensible 'I' who is structurally separated by the sonnet's volta, formally confined to the closed terminal couplet as she is spatially confined to the headland overlooking the sea. Resemblances remain as both living and dead are 'Press'd'/ 'opprest' by storms, and the speaker internalises the poem's environmental experience. ${ }^{67}$ Nonetheless, these connections are observed only to be severed: the churchyard of 'Sonnet XLIV' is not a projection of sensibility but an external context to which the narrator is intimately and uneasily related.$^{68}$ The disintegrating landscape symbolises the speaker's fractured sense of self, as the ' $\mathrm{I}$ ' is equally dispossessed of a fixed or stable position.

Smith's 'Sonnet XLIV' dramatically revised established methods of life writing for the dead. According to Fuss' definition of 'corpse poetry', as the dead body is transformed in the eighteenth century 'from an object of religious veneration' to 'spiritually irredeemable base matter', language intervenes to revive 'the dead through the vitalising properties of speech' and document 'the power of the corpse itself to keep historical memory alive'. ${ }^{69}$ Smith similarly works against the compensations of elegy through a process of exhumation and revelation. However, in 'Sonnet XLIV' this recovery is purely physical: the observer refuses to grant the dead a voice and rejects their significance as memorial objects.

The life of the narrator is necessarily implicated in this re-writing, as she is confronted by a 'monstrous alterity' that 'refuses to be contained within the familiar taxonomies through which we organise the world'. ${ }^{70}$ The shift to an inner storm becomes possible and urgent when the foundational role of the dead for the living is washed away. Juxtaposed with the energetic but de-identified corpse, Smith's 'I' has an animating inner life sustained by an agitation of spirit but is without animation: 
her static body on the shore assumes the inactivity usually ascribed to the restful corpse, becoming a living-dead figure. The narrative of her life is juxtaposed with the life writing of the dead and becomes, next to their life-in-death, a form of death-in-life. Stood at a mortal threshold, she is appropriately present in the churchyard as a space-in-flux, a site of (poetic) composition and termination. Like this marginal headland site, the narrator is precariously balanced; faced with its humic foundations, she transforms the once-reliable roots of civilisation to a source of selfquestioning anxiety.

The process by which this is achieved is potently un-earthing. In Harrison's neo-Vichian terms, the inscribable, absorbable earth constitutes a 'foothold for human worldhood' ${ }^{71}$ Using the sea to un-earth the defining humus, the idealised, collective identity of the dead marked in the soil is drowned out. The sea is the apocalyptic 'imaginary agent of ultimate obliteration' in its antagonism to 'imprinted memory'; inhuman in 'its passion for erasure' and set against the earth's solidity on which resurrection depends, the sea 'closes over rather than keeps the place of its dead, while its unbounded grave remains humanly unmarked'. ${ }^{72}$ In biblical terms, the sea is 'the symbol of the primordial undifferentiated flux [...] that state of barbaric vagueness and disorder out of which civilisation has emerged and into which, unless saved by the efforts of gods and men, it is always liable to relapse' ${ }^{73}$

Smith's exhumed skeletons can be usefully compared to the 'little recess full of coffins, which contains bodies embalmed long since', described in Mary Wollstonecraft's Letters Written During a Short Residence in Sweden, Norway and Denmark (1796). The 'human petrifactions' in the church in Tonsberg elicit 'disgust and horror': Wollstonecraft deplores this 'treason against humanity, thus to lift up the awful veil which would fain hide its weakness [...] nothing is so ugly as the human form when deprived of life'. She then personalises-'I would not see a form I loved-embalmed in my heart-thus sacrilegiously handled!'-and internalises-'Pugh! my stomach turns'- the corpse, drawing it closer despite herself. This experience provokes the observer's confrontation with her own 'littleness', as she asks 'Life, what art thou? Where goes this breath? this $I$, so much alive?'. ${ }^{74}$ As Clare Brant suggests, in this description the corpses are to be imagined 'privately and through previous attachment, and otherwise distinguished only by their absence of distinction'. Brant compares Wollstonecraft's withdrawal of positive emotional engagement towards the dead with Nathaniel Wraxall's earlier encounter with similarly preserved bodies, related in his Cursory Remarks made in a Tour through Some of the Northern Parts of Europe (1775). Where Wollstonecraft reluctantly contemplates the dead, Wraxall intimately engages with a particular corpse, 
hanging 'longingly over her body, touching her, lifting her up from her oak coffer by her hair, still glossy and brown, of which he cuts a lock'. ${ }^{75}$

Unlike the corpses in the church, and set against the water and rocks of the surrounding landscape, the "church-yard is almost the only verdant spot [...] Here, indeed, friendship extends beyond the grave; and, to grant a sod of earth, is to accord a favour' ${ }^{76}$ In the churchyard bodies take up space invisibly, presenting only earth to the eye and therefore allowing the imagination to extend the life of the dead as purely, and consolingly, spiritual matter: 'Spirits unseen seemed to walk abroad, and flit from cliff to cliff, to sooth my soul to peace ${ }^{\prime}{ }^{77}$ Wollstonecraft repeatedly describes her own experience of the environment in these terms: at evening she is a 'hapless wight' carried into futurity by 'more than mortal music, and spirits of peace [who] walk abroad', and she remembers favoured views in terms of revenance: 'The grave has closed over a dear friend, the friend of my youth; still she is present with me, and I hear her soft voice warbling as I stray over the heath'. At the cataract near Fredericstadt, Wollstonecraft describes how 'my soul rose, with renewed dignity, above its cares-grasping at immortality-it seemed as impossible to stop the current of my thoughts, as of the always varying, still the same, torrent before me-I stretched out my hand to eternity, bounding over the dark speck of life to come'. As at the coast around Quistram, bare landscape offers a view of 'the bones of the world waiting to be clothed with every thing necessary to give life and beauty'. ${ }^{78}$ This spectral, imaginative animation of landscape is absorbed in the churchyard, where life-affirming ('verdant': fertile and of the spring) earth covers and protects the living image of the dead from the deathly reality of the uncovered corpse.

By contrast, when Wollstonecraft's encounter with the exposed corpse (which engenders 'disgust and horror') prompts her to ask '[w] here goes this breath? this $I$, so much alive?', she registers its ability to fracture the boundaries of a self forced to confront its own dissolution. This is characteristic of Julia Kristeva's concept of abjection. For Kristeva the corpse is the ultimate representation of the abject, a revolt of being 'against a threat that seems to emanate from an exorbitant outside or inside, ejected beyond the scope of the possible, the tolerable, the thinkable. It lies there, quite close, but it cannot be assimilated'; the abject is 'opposed to $I$ '. It 'fascinates desire', which remains apprehensive and 'sickened, it rejects' yet simultaneously persists in 'a vortex of summons and repulsion [that] places the one haunted by it literally beside himself' ${ }^{79}$ Embodying this phenomenon, the corpse

upsets even more violently the one who confronts it as fragile and fallacious chance [...] corpses show me what I permanently thrust aside in order to live $[\ldots]$ the corpse, the most sickening of wastes, is a border that has 
encroached upon everything. It is no longer I who expel, 'I' is expelled [...] I behold the breaking down of a world that has erased its borders [...] It is death infecting life. ${ }^{80}$

These feelings react most strongly to the exposed body, which, in biblical terms, 'must not be displayed but immediately buried so as not to pollute the divine earth'. ${ }^{81}$ As Kate Woodthorpe's research in the City of London Cemetery and Crematorium reveals, a 'social silence regarding the reality of the dissolution of buried bodies in the cemetery' persists, making the 'abject nature' of decaying corpses a taboo subject into the twenty-first century. Despite the fact that bodies literally and metaphorically underpin the cemetery's spatial identity, their uncontrollable decomposition 'presents an absolute rejection of efforts to order and control the body' in the landscape. ${ }^{82}$ Wollstonecraft's embalmed cadavers and Smith's unearthed bones, according to Kristeva's criteria, expose that which ought not to be seen-a challenge to the living self that is both disruptive and compelling.

In his 'Essays upon Epitaphs' (1810) Wordsworth-whose brother John died at sea in $1805^{83}$-also reflected on sea-borne corpses as the basis for his consideration of reverent and irreverent treatment of the dead, respectfully buried or cared for no more 'than for the dead body of a seal or porpoise which might have been cast up by the waves'. He compared his experience of the calm of the churchyard to the sensations "which have arisen in my mind while I have been standing by the side of a smooth Sea'. Remembering the unsettled reality of the deceased's former lives, however, 'my fancy has penetrated into the depths of that Sea-with accompanying thoughts of Shipwreck, of the destruction of the Mariner's hopes, the bones of drowned Men heaped together, monsters of the deep'. ${ }^{84}$

Uncannily consolidating Wollstonecraft's destabilising cadavers, earth-bound churchyard, and disruptive torrent—and anticipating Wordsworth's metaphorical contrast between smooth and tempestuous seas and human lives-Smith's fragments on the shore can be understood as Kristeva's 'jettisoned object' that 'draws me toward the place where meaning collapses'. ${ }^{85}$ The skeletons reflect a negative impression of the observing self, dramatically opposing the churchyard's physical closure of the corpse and imaginative construction of community. The visceral, abject animation of the dead is shocking as it reverses the resolution of burial - a ritual that marks an end to life, which is here persistent and disturbing. Rising from their beds and tossed among the waves, the dead are given a ghastly semblance of liveliness. As they are forced from their churchyard locality in 'Sonnet XLIV', the dead are also disconnected from the community of which it forms the centre. It is this disconnection 
that destabilises the basis of the speaker's life: faced with mere bones, the narrator draws close to death that infects life.

\section{CONCLUSION}

Horrocks argues that corpses underlie Smith's poetry, lurking 'beneath the surface from the very beginning' ${ }^{86}$ This is manifested explicitly in the churchyard, but when unearthed the dead constitute an unearthly confrontation with death that provokes the question: on what does the self rely? In this context 'Sonnet XLIV' constitutes Smith's major intervention in churchyard literature-a genre with which she was demonstrably familiar and from which she dramatically departed. However, this poem goes further than a self-aware commentary on literary fraternity. Through the churchyard, as a venue for poetry but also human society and history, Smith confronts the reclamation of the dead by the living through established methods of life writing. She also questions the life writing of the living-grounded in the community of the churchyard, where humic foundations embody transmortal ties and the regulated orders of existence on which we depend-when these consolatory processes are eroded.

Harrison argues that 'the corpse is one of the most primordial of human institutions' in its intimate personification of 'what is on its way elsewhere': it is vital in its embodiment of 'passage', perpetuated in funeral rites that allow the dead to separate 'from their remains so that their images may find their place in the afterlife of the imagination'. ${ }^{87}$ Smith's skeletons uproot, rather than anchor, the sense of self: they are not the 'perfect likeness of the person who has passed away', but merely unspecified remains. ${ }^{88}$ The corpse that is 'reduced to an anonymous materiality' is disturbing, as it denies the conceptualisation of death as continuity or rebirth-beliefs that 'draw the receding corpse back into the social system' and reduce the fear of death as social erasure through memorial acts of recovery including space-making and -marking rituals for the dead. ${ }^{89}$ As Harrison writes, '[w] here the dead are simply dead, the living are in some sense already dead as well'.$^{90}$ Collapsing Caillois' 'tidy haven' onto an inhuman (because non-humic) coastal accumulation, Smith un-earths the fragile foundations of civilisation.

\section{WORKS CITED}

Andrews, Kerri. "“Herself... Fills the Foreground”: Negotiating Autobiography in the Elegiac Sonnets and The Emigrants.' In: Jacqueline Labbe (ed.), Charlotte Smith in British Romanticism. London: Pickering \& Chatto, 2008, 13-29. 
Anonymous. 'Sonnet to Mrs. Smith.' The European Magazine 10 (August 1786) 125.

Anonymous. 'Review of The Emigrants.' The European Magazine 24 (July 1793) 41-45.

Anonymous. 'Leviter Eruditus.' The Gentleman's Magazine, and Historical Chronicle 66 (June 1796) 489-90.

Anonymous. 'Letter.' The Gentleman's Magazine, and Historical Chronicle 67 (March 1797) 729.

Ariès, Philippe. The Hour of Our Death (1977). Trans. Helen Weaver. Oxford: Oxford University Press, 1991.

Auden, W. H. The Enchafed Flood, or the Romantic Iconography of the Sea. London: Faber and Faber, 1985.

Backscheider, Paula R. Eighteenth-Century Women Poets and Their Poetry: Inventing Agency, Inventing Genre. Baltimore: The Johns Hopkins University Press, 2005.

Baker, John. "'The Philosophy of Tears": Sense(s) and Sensibility in some Graveyard Poems.' Ètudes Èpistémè 30 (2016) 1-52.

Bakhtin, Mikhail M. 'Forms of Time and of the Chronotope in the Novel: Notes toward a Historical Poetics.' In: Michael Holquist (ed.), The Dialogic Imagination: Four Essays by M. M. Bakhtin. Trans. Caryl Emerson and Michael Holquist. Texas: University of Texas Press, 2008.

Batchelor, Jennie. Women's Work: Labour, Gender, Authorship, 1750-1830. Manchester: Manchester University Press, 2010.

Batchelor, Jennie. 'Jane Austen and Charlotte Smith: Biography, Autobiography and the Writing of Women's Literary History.' In: Daniel Cook and Amy Culley (eds.), Women's Life Writing, 1700-1850: Gender, Genre and Authorship. Basingstoke: Palgrave Macmillan, 2012, 181-196.

Bewell, Alan. Wordsworth and the Enlightenment: Nature, Man, and Society in the Experimental Poetry. New Haven: Yale University Press, 1989.

Blair, Robert. The Grave. A Poem. (1743) Augustan Reprint Society. Vol. 161. Los Angeles: William Andrews Clark Memorial Library, University of California, 1973.

Brant, Clare. 'Climates of Gender.' In: Amanda Gilroy (ed.), Romantic Geographies: Discourses of Travel 1775-1844. Manchester: Manchester University Press, 2000, 129-150.

Brooks, Stella. 'The Sonnets of Charlotte Smith.' Critical Survey 4:1 (1992) 9-21.

Burgess, Frederick. English Churchyard Memorials (1963). Cambridge: The Lutterworth Press, 2004.

Caillois, Roger. 'Patagonia' (1942). In: Claudine Frank (ed.), The Edge of Surrealism: A Roger Caillois Reader. Trans. Claudine Frank and Camille Naish. London: Duke University Press, 2003, 240-252.

Child, Mark. Discovering Churchyards. Aylesbury: Shire Publications Ltd., 1982.

Curran, Stuart. 'Charlotte Smith, Mary Wollstonecraft, and the Romance of Real Life.' In: Jacqueline M. Labbe (ed.), The History of British Women's Writing, 1750-1830, Volume Five. Basingstoke: Palgrave Macmillan, 2010, 194-206.

Davis, J. B. The Origin and Description of Bognor or Hothampton. London: Samuel Tipper, 1807.

Dolan, Elizabeth A. Seeing Suffering in Women's Literature of the Romantic Era. Farnham: Ashgate Publishing Ltd., 2008.

Doodson, Valerie. 'All about Tides.' https://www.ntslf.org/about-tides/tides. Date accessed: 28 August 2019.

Draper, John W. The Funeral Elegy and the Rise of English Romanticism. New York: The New York University Press, 1929.

Fairer, David. English Poetry of the Eighteenth Century 1700-1789. London: Longman, 2003.

Fuss, Diana. Dying Modern: A Meditation on Elegy. Durham: Duke University Press, 2013.

Genette, Gérard. Paratexts: Thresholds of Interpretation. Trans. Jane E. Lewin. Cambridge: Cambridge University Press, 1997. 
Gillis, John R. The Human Shore: Seacoasts in History. Chicago: The University of Chicago Press, 2012.

Girten, Kristin M. 'Charlotte Smith's Tactile Poetics.' The Eighteenth Century 54:2 (2013) 215-230.

Gray, Thomas. In: Roger Lonsdale (ed.), The Poems of Thomas Gray, William Collins, Oliver Goldsmith. London: Longmans, 1969.

Hallam, Elizabeth and Jenny Hockey. Death, Memory and Material Culture (2001). Oxford: Berg, 2006.

Hansen, Michael. 'Elegy, Ode, and the Eighteenth-Century Sonnet Revival: The Case of Charles and Emily.' Literary Imagination 12:3 (2010) 307-318.

Harrison, Robert Pogue. The Dominion of the Dead. Chicago: The University of Chicago Press, 2003.

Herbe, Sarah. "Thou liv'st to all that Read": Reading the Paratext of William Cartwright's Comedies, Tragi-Comedies, with other Poems (1651) as Early Modern Life Writing.' The European Journal of Life Writing III (2014) VC1-VC18.

Horrocks, Ingrid. Women Wanderers and the Writing of Mobility, 1784-1814. Cambridge: Cambridge University Press, 2017.

Jacobus, Mary. Romantic Things: A Tree, A Rock, A Cloud (2012). Chicago and London: The University of Chicago Press, 2015.

Kelley, Theresa M. 'Romantic histories: Charlotte Smith and Beachy Head.' Nineteenth-Century Literature 59:3 (2004) 281-314.

Kilian, Eveline and Hope Wolf (eds.). 'Introduction: The Spatial Dimensions of Life Writing.' In: Life Writing and Space. Farnham: Ashgate, 2016, 1-21.

Knowles, Claire. Sensibility and Female Poetic Tradition, 1780-1860: The Legacy of Charlotte Smith. Farnham: Ashgate, 2009.

Kristeva, Julia. Powers of Horror: An Essay on Abjection (1980). Trans. Leon S. Roudiez. New York: Columbia University Press, 1982.

Labbe, Jacqueline M. 'Selling One's Sorrows: Charlotte Smith, Mary Robinson, and the Marketing of Poetry.' The Wordsworth Circle 25:2 (1994) 68-71.

Labbe, Jacqueline M. Charlotte Smith: Romanticism, Poetry and the Culture of Gender. Manchester: Manchester University Press, 2003.

Labbe, Jacqueline M. (ed.). 'Introduction: Defining "Women's Writing"; or, Writing "the History".' In: The History of British Women's Writing, 1750-1830, Volume Five. Basingstoke: Palgrave Macmillan, 2010, 1-26.

Labbe, Jacqueline M. Writing Romanticism: Charlotte Smith and William Wordsworth, 1784-1807. Basingstoke: Palgrave Macmillan, 2011.

Lake, Crystal B. 'History Writing and Antiquarianism.' In: Devoney Looser (ed.), The Cambridge Companion to Women's Writing in the Romantic Period. Cambridge: Cambridge University Press, 2015, 88-101.

Laqueur, Thomas W. The Work of the Dead: A Cultural History of Mortal Remains. Princeton: Princeton University Press, 2015.

Leeuwen, Evert Jan Van. 'Funeral Sermons and Graveyard Poetry: The Ecstasy of Death and Bodily Resurrection.' Journal for Eighteenth-Century Studies 32:3 (2009) 353-371.

Lokke, Karri. 'Charlotte Smith and Literary History: "Dark Forgetfulness" and the "Intercession of Saint Monica"' Women's Studies: An Interdisciplinary Journal 27:3 (1998) 259-280.

Means, James A. 'Introduction'. In: The Grave. A Poem. (1743) Augustan Reprint Society. Vol. 161. Los Angeles: William Andrews Clark Memorial Library, University of California, 1973, i-x.

Mills, Rebecca. 'The Elegiac Tradition and the Imagined Geography of the Sea and the Shore.' Interdisciplinary Literary Studies 17:4 (2015) 493-516.

Mulvey-Roberts, Marie. Dangerous Bodies: Historicising the Gothic Corporeal. Manchester: Manchester University Press, 2016. 
Parisot, Eric. Graveyard Poetry: Religion, Aesthetics and the Mid-Eighteenth-Century Poetic Condition. Farnham: Ashgate, 2013.

Pascoe, Judith. 'Female Botanists and the Poetry of Charlotte Smith.' In: Carol Shiner Wilson and Joel Haefner (eds.), Re-Visioning Romanticism: British Women Writers, 1776-1837. Philadelphia: University of Pennsylvania Press, 1994, 193-210.

Phelan, Joseph. The Nineteenth-Century Sonnet. Basingstoke: Palgrave Macmillan, 2005.

Pinch, Adela. Strange Fits of Passion: Epistemologies of Emotion, Hume to Austen. Stanford: Stanford University Press, 1996.

Quinn, Vincent. 'Graveyard Writing and the Rise of the Gothic.' In: Angela Wright and Dale Townshend (eds.), Romantic Gothic: An Edinburgh Companion. Edinburgh: Edinburgh University Press, 2016, 37-54.

Roberts, Bethan. 'Literary Past and Present in Charlotte Smith's Elegiac Sonnets.' Studies in English Literature 1500-1900 54:3 (2014) 649-674.

Roberts, Bethan. "Breaking the Silent Sabbath of the Grave": Charlotte Smith's Sonnet XLIV and her Place in Literary History.' European Romantic Review 28:5 (2017) 549-570.

Roberts, Bethan. Charlotte Smith and the Sonnet: Form, Place and Tradition in the Late Eighteenth Century (Romantic Reconfigurations: Studies in Literature and Culture 1780-1850). Liverpool: Liverpool University Press, 2019.

Robinson, Daniel. 'Elegiac Sonnets: Charlotte Smith's Formal Paradoxy.' Papers on Language and Literature 39 (2003) 185-220.

Schmitt-Kilb, Christian. "Untranslated Landscape": Recent Poetic Prose of Kathleen Jamie and Paul Farley/Michael Symmons Roberts.' In: Ina Habermann and Daniela Keller (eds.), English Topographies in Literature and Culture: Space, Place, and Identity. Leiden: Brill, 2016, 25-40.

Schor, Esther. Bearing the Dead: The British Culture of Mourning from the Enlightenment to Victoria. Princeton: Princeton University Press, 1994.

Schwalm, Helga. 'Literary Configurations of the Peripatetic.' In: Eveline Kilian and Hope Wolf (eds.), Life Writing and Space. Farnham: Ashgate, 2016, 75-89.

Sharpe, Kevin and Steven N. Zwicker (eds.). 'Introducing Lives.' In: Writing Lives: Biography and Textuality, Identity and Representation in Early Modern England. Oxford: Oxford University Press, 2008.

Smith, Adam. In: Ryan Patrick Hanley (ed.), The Theory of Moral Sentiments (1759). London: Penguin Books, 2009.

Smith, Charlotte. Marchmont (1796). Delmar: Scholars' Facsimiles \& Reprints, 1989.

Smith, Charlotte. Montalbert (1795). Delmar: Scholars' Facsimiles \& Reprints, 1989.

Smith, Charlotte. In: Stuart Curran (ed.), The Poems of Charlotte Smith. Oxford: Oxford University Press, 1993.

Smith, Charlotte. In: Antje Blank and Janet Todd (eds.), Desmond (1792). Peterborough: Broadview Editions, 2001.

Smith, Charlotte. In: Loraine Fletcher (ed.), Celestina (1791). Peterborough: Broadview Editions, 2004.

Smith, Charlotte. In: Ellen Moody (ed.), Ethelinde, or the Recluse of the Lake (1789). Richmond: Valancourt Books, 2016.

Stewart, Susan. The Poet's Freedom: A Notebook on Making. Chicago: The University of Chicago Press, 2011.

Vico, Giambattista. New Science: Principles of the New Science Concerning the Common Nature of Nations. Third Edition (1744). Trans. David Marsh. London: Penguin Books, 2013.

Weisman, Karen A. 'Form and Loss in Charlotte Smith's "Elegiac Sonnets".' The Wordsworth Circle 33:1 (2002) 23-27.

Wittgenstein, Ludwig. In: G. E. M. Anscombe and G. H. von Wright (eds.), On Certainty. Trans. Denis Paul and G. E. M. Anscombe. New York: Harper and Row, 1972. 
Wollstonecraft, Mary. In: Tone Brekke and Jon Mee (eds.), Letters Written During a Short Residence in Sweden, Norway and Denmark (1796). Oxford: Oxford University Press, 2009.

Woodthorpe, Kate. 'Buried Bodies in an East London Cemetery: Re-Visiting Taboo.' In: Avril Maddrell and James D. Sidaway (eds.), Deathscapes: Spaces for Death, Dying, Mourning and Remembrance. Farnham: Ashgate Publishing Ltd., 2010.

Wordsworth, William. 'Essays upon Epitaphs' (1810). In: John O. Hayden (ed.), The Selected Prose of William Wordsworth. London: Penguin Books, 1988, 322-372.

Zimmerman, Sarah. 'Charlotte Smith's Letters and the Practice of Self-Presentation.' Princeton University Library Chronicle 53 (1991-1992) 50-78.

Zimmerman, Sarah M. Romanticism, Lyricism, and History. New York: State University of New York Press, 1999.

\section{ABOUT THE AUTHOR}

James Metcalf is a visiting research fellow at the Centre for Life-Writing Research at King's College London. He recently completed his doctoral thesis, entitled 'The Contemplators: Poetry and the Churchyard in the Long Eighteenth Century', which reappraises the conventional category of 'graveyard poetry' by focusing on the eighteenth-century occupation of the churchyard as the specific locus of a death-centred poetics of contemplation. Reconsidering the work of Thomas Parnell, Robert Blair, Edward Young, and Thomas Gray, James' thesis also reveals a continuity of poetic preoccupation with the churchyard by including traditionally 'Romantic' writers such as Charlotte Smith and William Wordsworth as they adopt and revise its history, culture, and poetics. His current research interests concern literary responses to the revelations of earth science in the long eighteenth century.

\section{NOTES}

1 Parisot, Eric. Graveyard Poetry: Religion, Aesthetics and the Mid-Eighteenth-Century Poetic Condition. Farnham: Ashgate, 2013 (1).

2 Curran, Stuart. 'Charlotte Smith, Mary Wollstonecraft, and the Romance of Real Life.' In: Jacqueline M. Labbe (ed.), The History of British Women's Writing, 1750-1830, Volume Five. Basingstoke: Palgrave Macmillan, 2010 (195, 200).

3 Smith, Charlotte. 'Preface to the First and Second Editions.' In: Stuart Curran (ed.), The Poems of Charlotte Smith. Oxford: Oxford University Press, 1993 (3).

4 Zimmerman, Sarah. 'Charlotte Smith's Letters and the Practice of Self-Presentation.' Princeton University Library Chronicle 53 (1991-1992) (60).

5 Anon. 'Review of The Emigrants.' The European Magazine 24 (July 1793) (42).

6 Anon. 'Sonnet to Mrs. Smith.' The European Magazine 10 (August 1786) (125).

7 Genette, Gérard. Paratexts: Thresholds of Interpretation. Trans. Jane E. Lewin. Cambridge: Cambridge University Press, 1997 (2, 197) reads paratexts as a 'zone not only of transition but also of transaction' between writer and reader, and between the external world of publishing and the internal world of the text; an authorial preface 'has its chief function to ensure that the text is read properly [...] its location is introductory and therefore monitory.' Sharpe, Kevin, and Steven N. Zwicker (eds.). 'Introducing Lives.' In: Writing Lives: Biography and Textuality, Identity and Representation in Early Modern England. Oxford: Oxford 
University Press, 2008 (7, 25) historicise paratexts as 'sites of early modern life writing' that produce 'fragmentary and episodic' autobiography before the popularisation of the 'Life of the Author'. Herbe, Sarah. "Thou liv'st to all that Read": Reading the Paratext of William Cartwright's Comedies, Tragi-Comedies, with other Poems (1651) as Early Modern Life Writing.' The European Journal of Life Writing vol. III (2014) (3-4) calls this a 'multigeneric, multi-perspective, and multi-modal form of life writing' allowing the reader to synthesise the text's splintered life writing.

8 See for instance Dolan, Elizabeth A. Seeing Suffering in Women's Literature of the Romantic Era. Farnham: Ashgate Publishing Ltd., 2008 (21-30); Labbe, Jacqueline M. Charlotte Smith: Romanticism, Poetry and the Culture of Gender. Manchester: Manchester University Press, 2003 (1, 18); Labbe, Jacqueline M. 'Selling One’s Sorrows: Charlotte Smith, Mary Robinson, and the Marketing of Poetry.' The Wordsworth Circle 25:2 (1994) (68).

9 Phelan, Joseph. The Nineteenth-Century Sonnet. Basingstoke: Palgrave Macmillan, 2005 $(34,43)$ argues that the sonnet is predisposed to personal revelation and that Smith's influence confirmed its reputation as 'a site of privileged autobiographical utterance'. While Smith uses the sonnet's revelatory potential, Kelley, Theresa M. 'Romantic Histories: Charlotte Smith and Beachy Head.' Nineteenth-Century Literature 59:3 (2004) (282283) suggests that she also exceeds the terms of its affiliation between speaker and subject by introducing 'the raw specifics of her personal circumstances so emphatically that the fictional guise of the sonneteer cannot hold.' For Zimmerman, Sarah M. Romanticism, Lyricism, and History. New York: State University of New York Press, 1999 (ix, 39, 48) Smith becomes at once the object and subject of her sonnet sequences, rendering them tableaux of 'miniature, verbal self-portraits'.

10 See for instance Knowles, Claire. Sensibility and Female Poetic Tradition, 1780-1860: The Legacy of Charlotte Smith. Farnham: Ashgate, 2009 (49); Roberts, Bethan. 'Literary past and present in Charlotte Smith's Elegiac Sonnets,' Studies in English Literature 1500-1900 $54: 3$ (2014) (649-651).

11 Kilian, Eveline and Hope Wolf (eds.). 'Introduction: The Spatial Dimensions of Life Writing.' In: Life Writing and Space. Farnham: Ashgate, 2016 (1, 5); Schmitt-Kilb, Christian. "Untranslated Landscape": Recent Poetic Prose of Kathleen Jamie and Paul Farley/Michael Symmons Roberts.' In: Ina Habermann and Daniela Keller (eds.), English Topographies in Literature and Culture: Space, Place, and Identity. Leiden: Brill, 2016 (25-26).

12 Kilian and Wolf, 2016 (5).

13 Schwalm, Helga. 'Literary Configurations of the Peripatetic.' In: Eveline Kilian and Hope Wolf (eds.), Life Writing and Space. Farnham: Ashgate, 2016 (75, 76).

14 Andrews, Kerri. "Herself... Fills the Foreground": Negotiating Autobiography in the Elegiac Sonnets and The Emigrants.' In: Jacqueline Labbe (ed.), Charlotte Smith in British Romanticism. London: Pickering and Chatto, 2008 (14); Knowles, Claire, 2009 (49, 55-56).

15 Fairer, David. English Poetry of the Eighteenth Century 1700-1789. London: Longman, 2003 (223).

16 Girten, Kristin M. 'Charlotte Smith's Tactile Poetics.' The Eighteenth Century 54:2 (2013) (215-230); Pascoe, Judith. 'Female Botanists and the Poetry of Charlotte Smith.' In: Carol Shiner Wilson and Joel Haefner (eds.), Re-Visioning Romanticism: British Women Writers, 1776-1837. Philadelphia: University of Pennsylvania Press, 1994 (193).

17 Backscheider, Paula R. Eighteenth-Century Women Poets and Their Poetry: Inventing Agency, Inventing Genre. Baltimore: The Johns Hopkins University Press, 2005 (325); Batchelor, Jennie. 'Jane Austen and Charlotte Smith: Biography, Autobiography and the Writing of Women's Literary History.' In: Daniel Cook and Amy Culley (eds.), Women's Life Writing 1700-1850: Gender, Genre and Authorship. Basingstoke: Palgrave Macmillan, 2012 (192).

18 Schor, Esther. Bearing the Dead: The British Culture of Mourning from the Enlightenment to Victoria. Princeton: Princeton University Press, 1994 (19, 65-66); Gray, Thomas. 'Elegy 
Written in a Country Churchyard.' In: Roger Lonsdale (ed.), The Poems of Thomas Gray, William Collins, Oliver Goldsmith. London: Longmans, 1969 (1. 16). See also Robinson, Daniel. 'Elegiac Sonnets: Charlotte Smith's Formal Paradoxy.' Papers on Language and Literature 39 (2003) (194) on how Smith renders 'Gray's "rude forefathers" superfluous and inconsequential by casting them out of their rustic cemetery only to be pulverised by the ocean.'

19 Gillis, John R. The Human Shore: Seacoasts in History. Chicago: The University of Chicago Press, 2012 (4-6, 137, 158).

20 Caillois, Roger. 'Patagonia.' In: Claudine Frank (ed.), The Edge of Surrealism: A Roger Caillois Reader. Trans. Claudine Frank and Camille Naish. London: Duke University Press, 2003 (245-247).

21 Laqueur, Thomas W. The Work of the Dead: A Cultural History of Mortal Remains. Princeton: Princeton University Press, 2015 (112-114).

22 Ariès, Philippe. The Hour of Our Death. Trans. Helen Weaver. Oxford: Oxford University Press, 1991 (70).

23 Child, Mark. Discovering Churchyards. Aylesbury: Shire Publications Ltd., 1982 (13-19).

24 Idem (14-23, 69); Burgess, Frederick. English Churchyard Memorials. Cambridge: The Lutterworth Press, 2004 (23-24).

25 Ariès, Philippe, 1991 (62-75).

26 Bakhtin, Mikhail M. 'Forms of Time and of the Chronotope in the Novel: Notes toward a Historical Poetics.' In: Michael Holquist (ed.), The Dialogic Imagination: Four Essays by M. M. Bakhtin. Trans. Caryl Emerson and Michael Holquist. Texas: University of Texas Press, 2008 (225).

27 Idem (250).

28 Laqueur, Thomas W., 2015 (1, 10, 4, 17, 22).

29 Caillois, Roger, 2003 (250).

30 Bewell, Alan. Wordsworth and the Enlightenment: Nature, Man, and Society in the Experimental Poetry. New Haven: Yale University Press, 1989 (188, 194-195).

31 Idem (190).

32 Vico, Giambattista. New Science: Principles of the New Science Concerning the Common Nature of Nations. Third Edition (1744). Trans. David Marsh. London: Penguin Books, 2013 $(8,9,223,225)$.

33 Harrison, Robert Pogue. The Dominion of the Dead. Chicago: The University of Chicago Press, 2003 (ix-xi).

34 Schor, Esther, 1994 (35, 20).

35 Smith, Adam. In: Ryan Patrick Hanley (ed.), The Theory of Moral Sentiments. London: Penguin Books, 2009 (17-18).

36 Schor, Esther, 1994 (8).

37 Baker, John. "'The Philosophy of Tears": Sense(s) and Sensibility in Some Graveyard Poems.' Ėtudes Èpistémè 30 (2016) (4); Laqueur, Thomas W., 2015 (114).

38 Laqueur, Thomas W., 2015 (144).

39 Blair, Robert. The Grave. A Poem. (1743) Augustan Reprint Society. Vol. 161. Los Angeles: William Andrews Clark Memorial Library, University of California, 1973 (11. 169-171, 745, 752-753). Means, James A. 'Introduction.' In: The Grave. A Poem. (1743) Augustan Reprint Society. Vol. 161. Los Angeles: William Andrews Clark Memorial Library, University of California, 1973 (i) argues that Blair's 'macabre details' were 'subordinated in his mind to this central evangelical theme.'

40 See for instance Draper, John W. The Funeral Elegy and the Rise of English Romanticism. New York: The New York University Press, 1929; Leeuwen, Evert Jan Van. 'Funeral Sermons and Graveyard Poetry: The Ecstasy of Death and Bodily Resurrection.' Journal for Eighteenth-Century Studies 32:3 (2009) (353-371); Quinn, Vincent. 'Graveyard Writing 
and the Rise of the Gothic.' In: Angela Wright and Dale Townshend (eds.), Romantic Gothic: An Edinburgh Companion. Edinburgh: Edinburgh University Press, 2016 (37-54).

41 Fuss, Diana. Dying Modern: A Meditation on Elegy. Durham: Duke University Press, 2013 (7).

42 Smith, Charlotte. Montalbert. Delmar: Scholars' Facsimiles \& Reprints, 1989 (vol. II, 62-89).

43 See for instance Hansen, Michael. 'Elegy, Ode, and the Eighteenth-Century Sonnet Revival: The Case of Charles and Emily.' Literary Imagination 12:3 (2010) (312); Labbe, Jacqueline M. Writing Romanticism: Charlotte Smith and William Wordsworth, 1784-1807. Basingstoke: Palgrave Macmillan, 2011 (115). Quoted in Roberts, Bethan. "Breaking the Silent Sabbath of the Grave": Charlotte Smith's Sonnet XLIV and her Place in Literary History.' European Romantic Review 28:5 (2017) (550).

44 Pinch, Adela. Strange Fits of Passion: Epistemologies of Emotion, Hume to Austen. Stanford: Stanford University Press, 1996 (59).

45 Schor, Esther, 1994 (65-66).

46 Horrocks, Ingrid. Women Wanderers and the Writing of Mobility, 1784-1814. Cambridge: Cambridge University Press, 2017 (93-94). See also: Brooks, Stella. 'The sonnets of Charlotte Smith.' Critical Survey 4:1 (1992) (14); Lokke, Karri. 'Charlotte Smith and Literary History: "Dark Forgetfulness" and the "Intercession of Saint Monica". Women's Studies: An Interdisciplinary Journal 27:3 (1998) (263-267); Roberts, Bethan. Charlotte Smith and the Sonnet: Form, Place and Tradition in the Late Eighteenth Century (Romantic Reconfigurations: Studies in Literature and Culture 1780-1850). Liverpool: Liverpool University Press, 2019 (156-158).

47 Labbe, Jacqueline M. (ed.). 'Introduction: Defining "Women's Writing”; or, Writing "the History".' In: The History of British Women's Writing, 1750-1830, Vol. 5. Basingstoke: Palgrave Macmillan, 2010 (13).

48 Roberts, Bethan, 2019 (83, 99).

49 Gray, Thomas, 1969 (1. 1); Smith, Charlotte. 'Sonnet XLIV. Written in the Church-Yard at Middleton in Sussex.' In: Stuart Curran (ed.), The Poems of Charlotte Smith. Oxford: Oxford University Press, 1993 (1. 11).

50 Schor, Esther, 1994 (66).

51 Doodson, Valerie. 'All about tides.' https://www.ntslf.org/about-tides/tides. Date accessed: 28 August 2019.

52 Stewart, Susan. The Poet's Freedom: A Notebook on Making. Chicago: The University of Chicago Press, 2011 (192-193) reads maternity into gendered definitions of creative acts, which distinguish between masculine work 'which has some manifested consequence' and feminine labour 'which becomes erased back into time and nature': the differences between labour and work are 'set out starkly in gendered terms that make the labour of childbirth the paradigm for gratuitous suffering.' This is evident in Smith's work, as she frequently presents the writer's body as a poetic point of origin by combining a maternal persona duty-bound to write with repeated references to writing as a labour particularly difficult for women but also, paradoxically, one of their only means of intellectual and artistic self-realisation—see Batchelor, Jennie. Women's Work: Labour, Gender, Authorship, 1750-1830. Manchester: Manchester University Press, 2010 (67-68) and Dolan, Elizabeth A., 2008 (1-3). On the intersection of the authorial body with the 'body of poetry' see Labbe, Jacqueline M., 1994 (68-69).

53 Schor, Esther, 1994 (65).

54 Mills, Rebecca. 'The Elegiac Tradition and the Imagined Geography of the Sea and the Shore.' Interdisciplinary Literary Studies 17:4 (2015) (494).

$55 \operatorname{Idem}(499,500)$.

56 Roberts, Bethan, 2017 (558-559).

57 Zimmerman, Sarah, 1991-1992 (66-67). 
58 On footnotes in 'Beachy Head' crowding 'the pages like buried objects' see Lake, Crystal B. 'History Writing and Antiquarianism.' In: Devoney Looser (ed.), The Cambridge Companion to Women's Writing in the Romantic Period. Cambridge: Cambridge University Press, 2015 (95).

59 Genette, Gérard, 1997 (328).

60 Wittgenstein, Ludwig. In: G. E. M. Anscombe and G. H. von Wright (eds.), On Certainty. Trans. Denis Paul and G. E. M. Anscombe. New York: Harper and Row, 1972 (15) makes a distinction between 'hard rock, subject to no alteration' and 'sand, which now in one place now in another gets washed away'-an analogy he draws in reference to 'the riverbed of thoughts' but which is applicable to Smith's ostensibly stable earth of the churchyard undermined onto the mercurial sands of the coastline.

61 Despite protective measures being taken in 1779 , by 1838 the church had fallen into the sea and by 1847 all vestiges had been swept away and were replaced on an inland site two years later. For a history of Middleton Church and its connection with Smith see Roberts, Bethan, 2019 (122-125).

62 Anon. 'Leviter Eruditus.' The Gentleman's Magazine 66 (June 1796) (489). Quoted in Roberts, Bethan, 2019 (122).

63 Anon. 'Letter.' The Gentleman's Magazine 67 (March 1797) (729). Quoted in Roberts, Bethan, 2019 (122).

64 Roberts, Bethan, 2019 (122).

65 Davis, J. B. The Origin and Description of Bognor or Hothampton. London: Samuel Tipper, 1807 (100). Quoted in Roberts, Bethan, 2019 (124-125).

66 Roberts, Bethan, 2019 (125-126).

67 Girten, Kristin, 2013 (215-217); Weisman, Karen. 'Form and Loss in Charlotte Smith's "Elegiac Sonnets".' The Wordsworth Circle 33:1 (2002) (25). Zimmerman, Sarah M., 1999 (53) also points out Sonnet XLIV's simultaneity of natural event and psychological revelation.

68 Fairer, David, 2003 (225).

69 Fuss, Diana, 2013 (46-47, 67).

70 Mulvey-Roberts, Marie. Dangerous Bodies: Historicising the Gothic Corporeal. Manchester: Manchester University Press, 2016 (3).

71 Harrison, Robert Pogue, 2003 (4).

$72 \operatorname{Idem}(4,13,12)$.

73 Auden, W. H. The Enchafèd Flood, or the Romantic Iconography of the Sea. London: Faber and Faber, 1985 (16-17).

74 Wollstonecraft, Mary. In: Tone Brekke and Jon Mee (eds.), Letters Written During a Short Residence in Sweden, Norway and Denmark. Oxford: Oxford University Press, 2009 (48-49).

75 Brant, Clare. 'Climates of Gender.' In: Amanda Gilroy (ed.), Romantic Geographies: Discourses of Travel 1775-1844. Manchester: Manchester University Press, 2000 (141-142).

76 Wollstonecraft, Mary, 2009 (72).

77 Ibidem.

78 Idem $(16,39,89,28)$.

79 Kristeva, Julia. Powers of Horror: An Essay on Abjection. Trans. Leon S. Roudiez. New York: Columbia University Press, 1982 (1).

80 Idem (3-4).

81 Idem (109).

82 Woodthorpe, Kate. 'Buried Bodies in an East London Cemetery: Re-Visiting Taboo.' In: Avril Maddrell and James D. Sidaway (eds.), Deathscapes: Spaces for Death, Dying, Mourning and Remembrance. Farnham: Ashgate Publishing Ltd., 2010 (58, 64).

83 On the impact of his brother's death on Wordsworth's poetry, particularly in its elegiac mode, see Jacobus, Mary. 'Chapter 5 "Distressful Gift": Talking to the Dead.' In: 
Romantic Things: A Tree, A Rock, A Cloud. Chicago and London: The University of Chicago Press, 2015 (94-114).

84 Wordsworth, William. 'Essays upon Epitaphs.' In: John O. Hayden (ed.), The Selected Prose of William Wordsworth. London: Penguin Books, 1988 (326, 338).

85 Kristeva, Julia, 1982 (2).

86 Horrocks, Ingrid, 2017 (108).

87 Harrison, Robert Pogue, 2003 (92-93, 147-148).

88 Idem (92).

89 Hallam, Elizabeth and Jenny Hockey. Death, Memory and Material Culture. Oxford: Berg, $2006(89,4,131,133)$.

90 Harrison, Robert Pogue, 2003 (123). 